\title{
SINYAL LABA DALAM PERISTIWA PEMECAHAN SAHAM DI BURSA EFEK INDONESIA
}

\author{
Naning Margasari, Muniya Alteza, \& Musaroh \\ Universitas Negeri Yogyakarta, Indonesia \\ Email: margasarine@yahoo.com
}

\begin{abstract}
Abstrak: Sinyal Laba dalam Peristiwa Pemecahan Saham di Bursa Efek Indonesia. Penelitian ini bertujuan untuk menguji pengaruh informasi privat dalam peristiwa pemecahan saham yang diproksikan dengan split factor signal terhadap kinerja keuangan perusahaan yang diukur melalui laba bersih sesudah pajak, pertumbuhan laba bersih sesudah pajak dan laba per lembar saham. Total sampel yang dikumpulkan sesuai kriteria purposive sampling mencakup 55 sampel pemecahan saham. Teknik analisis data menggunakan regresi linear berganda. Hasil penelitian menunjukkan bahwa split factor signal berpengaruh positif dan signifikan terhadap terhadap kinerja keuangan yang diukur menggunakan laba bersih sesudah pajak perusahaan. Penelitian ini juga menemukan bahwa split factor signal tidak berpengaruh terhadap kinerja keuangan yang diukur menggunakan pertumbuhan laba bersih sesudah pajak dan laba per lembar saham.
\end{abstract}

Kata kunci: pemecahan saham, split factor signal, laba bersih sesudah pajak, pertumbuhan laba bersih sesudah pajak, laba per lembar saham

\begin{abstract}
Profitability Signal of Stock Split Events in Indonesia Stock Exchange. This research aimed to test the effects of private information in stock split as proxied by split factor signal toward financial performance of firms as measured by earning after tax, growth of earning after tax and earning per share. The total samples collected based on purposive sampling criteria were 55 stock splits. Data analysis was conducted through multiple linear regression. The result of this research showed that split factor signal had positive and significant effect on financial performance masured by earning after tax. Besides that the results indicated that split factor signal had no significant effect on the financial performance measured by growth of earning after tax and earning per share.
\end{abstract}

Keywords: stock split, split factor signal, earning after tax, growth of earning after tax, earning per share

\section{PENDAHULUAN}

Pemecahan saham (stock split) merupakan salah satu corporate action yang banyak dilakukan oleh perusahaan publik yang terdaftar di Bursa Efek Indonesia. Dalam pemecahan saham perusahaan akan memecah selembar saham menjadi $n$ lembar saham. Harga per lembar saham nantinya setelah pemecahan saham akan menjadi $1 / n$ harga sebelumnya. Keputusan melakukan pemecahan saham oleh suatu perusahaan merupakan kesepakatan para pemegang saham yang dibicarakan dalam rapat umum pemegang saham (RUPS). Pemecahan saham dikategorikan sebagai suatu peristiwa yang dapat memengaruhi efek perusahaan atau keputusan investasi pemodal, karena menyebabkan terjadinya perubahan nilai nominal saham, nilai pasar saham, dan jumlah saham yang beredar. Oleh karena itu, 
maka keputusan pemecahan saham harus segera diumumkan pada masyarakat sesuai dengan ketentuan yang berlaku melalui pengumuman di bursa serta di surat kabar yang terbit di Indonesia.

Pemecahan saham memiliki beberapa karakteristik sebagai berikut: 1) nilai pasar saham menjadi berkurang; 2) tidak terdapat perubahan nilai kapitalisasi; 3) proporsi kepemilikan saham tidak mengalami perubahan; 4) terdapat penurunan pada nilai buku perusahaan, earning per share dan harga pasar per saham; dan 5) terjadi pencapaian optimal trading range untuk harga pasar per saham (Cahyaning, 2005). Pemecahan saham ada dua jenis yaitu pertama, pemecahan naik (split up) adalah penurunan nilai nominal per lembar saham yang mengakibatkan bertambahnya jumlah lembar saham beredar dengan split factor tertentu. Kedua, pemecahan turun (split down atau reverse stock split) adalah peningkatan nilai nominal per lembar saham dan mengurangi jumlah saham beredar dengan split factor tertentu.

Hingga saat ini terdapat pandangan beragam mengenai motivasi perusahaan melakukan pemecahan saham. Pendapat pertama menyatakan bahwa pemecahan saham merupakan corporate action yang sifatnya adalah kosmetik dan administratif yaitu upaya memoles saham agar tampak lebih menarik di mata investor, di mana tindakan ini hanya menyebabkan perubahan akuntansi lewat pengurangan par value tetapi tidak mengubah jumlah modal di neraca sehingga tidak mengubah kekayaan perusahaan (Sukardi, 2000:24). Tindakan pemecahan saham menimbulkan efek fatamorgana saja di mana investor seolah- olah menjadi lebih makmur karena memegang lembar saham dalam jumlah lebih banyak. Padahal penambahan lembar saham yang dimiliki juga diiringi dengan penurunan nilai per lembar saham. Dari sini bisa disimpulkan bahwa pemecahan saham sebenarnya tidak mengandung nilai ekonomis. Meski demikian, banyaknya peristiwa pemecahan saham yang terjadi di Bursa Efek Indonesia tetap mengindikasikan bahwa pemecahan saham merupakan salah satu instrumen penting yang dipakai perusahaan di pasar modal.

Penjelasan lain yang mendasari pemecahan saham terkait dengan kandungan informasi dari pemecahan saham. Penelitian yang dilakukan memperlihatkan hasil yang beragam dan tidak konsisten. Ada yang membuktikan bahwa pemecahan saham berpengaruh terhadap variabel harga dan likuiditas saham dan ada pula yang sebaliknya. Fatmawati dan Asri (1998) melakukan penelitian pada 30 sampel perusahaan yang melakukan pemecahan saham di BEJ selama bulan Juli 1995-Juni 1997. Penelitian ini menguji pengaruh pemecahan saham terhadap likuiditas saham yang diukur dengan besarnya bid-ask spread di BEJ. Kesimpulan dari penelitian ini bahwa secara keseluruhan aktivitas pemecahan saham berpengaruh secara signifikan terhadap tingkat harga saham, volume turnover, dan persentase spread. Penelitian oleh Haryanto dan Hermawan (2005) menguji dampak pemecahan saham terhadap likuiditas dan abnormal return saham perusahaan di BEJ periode Januari 1999-Desember 2003. Dari hasil pengujian statistik pada periode 10 hari sebelum dengan 10 hari sesudah 
pengumuman pemecahan saham terhadap likuiditas saham tidak terdapat perbedaan yang signifikan. Penelitian oleh Cahyaning (2005) menguji dampak pemecahan saham terhadap return saham (perusahaan yang melakukan pemecahan saham periode 19992002) menggunakan periode penelitian 41 hari bursa, 30 hari bursa dari pengumuman perusahaan melakukan pemecahan saham, dan 11 hari sekitar tanggal pengumuman, yaitu 5 hari sebelum, 1 hari peristiwa, dan 5 hari sesudah pengumuman, variabel yang digunakan adalah actual return, expected return, abnormal return, dan pemecahan saham. Hasil dari penelitian tersebut menyatakan bahwa terdapat perbedaan signifikan antara return saham sebelum pengumuman dengan return saham setelah pemecahan saham, ada pengaruh pengumuman pemecahan saham terhadap abnormal return di sekitar hari peristiwa pada t0 dan $\mathrm{t}+1$, juga terdapat perbedaan signifikan mean abnormal return sebelum dan sesudah pemecahan saham. Dampak pemecahan saham terhadap keuntungan investor juga dijelaskan oleh Grinblatt et.al (1984) dalam Kurniawati (2003), bahwa di sekitar pengumuman pemecahan saham menunjukkan adanya perilaku harga saham yang abnormal.

Namun di sisi lain, Aggarwal dan Chen (dalam Miliasih, 2000) tidak menemukan adanya abnormal return berkaitan dengan pengumuman pemecahan saham Hasil berbeda juga ditemukan dalam pengujian Margaretha (2003) di mana tidak ada perbedaan signifikan rata-rata volume perdagangan saham sebelum dan sesudah pengumuman pemecahan saham, yang mengindikasikan pasar tidak bereaksi dengan adanya pemecahan saham. Sedangkan Nichols dan McDonald (1983) dalam Fatmawati dan Asri (1998) menyimpulkan adanya pasar yang anomali dimana dengan adanya pemecahan saham, laba perusahaan menjadi bertambah besar. Hal ini diperkuat oleh Asquith dalam Hartono (2003), yang melalui pengujiannya terhadap 121 perusahaan pada periode 1970-1980 menemukan bahwa perusahaan melakukan pemecahan saham setelah terjadi kenaikan terhadap laba perusahaan. Hasilnya adalah pengumuman pemecahan saham mempunyai dampak terhadap harapan investor akan kenaikan earning (sementara atau tetap) pada saat, sebelum, dan sesudah pengumuman pemecahan saham. Simpulan bertentangan dikemukakan oleh Miliasih (2000) yang meneliti dampak pemecahan saham terhadap earning. Berdasarkan data pemecahan saham selama satu tahun ternyata penelitiannya menunjukkan bahwa stock split berdampak negatif terhadap earning.

Alasan perusahaan melakukan pemecahan saham terkait dengan dua hal yaitu sinyal mengenai prospek perusahaan yang akan disampaikan kepada publik, tertuang dalam signaling theory dan kemahalan harga saham, dirumuskan dalam trading range theory. Signaling theory menyatakan bahwa pemecahan saham merupakan sinyal yang positif karena manajer perusahaan akan menginformasikan prospek masa depan yang baik dari perusahaan kepada publik yang belum mengetahuinya. Alasan sinyal ini didukung dengan adanya kenyataan bahwa perusahaan yang melakukan pemecahan saham adalah perusahaan yang mempunyai 
kondisi kinerja yang baik. Menurut teori ini, manajer dapat menggunakan peristiwa pemecahan saham untuk memberikan sinyal positif (good news) atau ekspektasi optimis kepada publik. Dalam hal ini pemecahan saham dianggap sebagai sinyal yang diberikan manajemen bahwa perusahaan memiliki prospek yang bagus di masa depan.

Tidak semua perusahaan dapat melakukan pemecahan saham. Hanya perusahaan yang sesuai dengan kondisi yang disinyalkan yang akan bereaksi positif. Perusahaan yang memberikan sinyal yang tidak valid akan mendapat dampak negatif. Copeland (1979) dalam Haryanto dan Hermawan (2005) menyatakan bahwa pemecahan saham yang dilakukan perusahaan memerlukan biaya yang harus ditanggung dan hanya perusahaan yang mempunyai prospek yang bagus yang dapat menanggung biaya.

Menurut trading range theory, perusahaan melakukan pemecahan saham untuk menata kembali rentang harga saham agar tidak terlalu mahal. Menurut teori ini, perusahaan yang melakukan pemecahan saham memiliki harga saham yang terlalu tinggi sehingga menurunkan daya beli investor dan menyebabkan kurang aktifnya saham tersebut diperdagangkan. Ketika harga saham mulai naik, sebagian investor akan merasa harga saham tersebut terlalu mahal untuk dibeli dan merasa tidak mampu lagi untuk berpartisipasi dalam perdagangan. Pemecahan saham akan membuat harga saham lebih rendah atau turun pada level tertentu sehingga terjangkau oleh investor. Akibatnya membuat harga saham lebih atraktif, permintaan saham akan cenderung meningkat, sehingga saham akan lebih aktif diperdagangkan di bursa.

Huang, Liano dan Pan (2002) merumuskan bahwa trading range theory tidak dapat menjelaskan latarbelakang perusahaan melakukan pemecahan saham apabila perusahaan melakukan pemecahan dengan split factor yang kecil. Alasannya split factor yang kecil tidak akan banyak membantu perusahaan untuk menurunkan harga saham kembali ke trading range yang optimal. Dengan demikian mestinya signaling theory yang mampu menjelaskan fenomena pemecahan saham dengan split factor kecil.

Menurut signaling theory pengumuman pemecahan saham dianggap sebagai sinyal yang diberikan oleh manajemen kepada publik bahwa perusahaan memiliki prospek bagus di masa depan. Manajemen mempunyai informasi lebih tentang prospek perusahaan dibandingkan pihak luar (investor). Para manajer perusahaan menggunakan pemecahan saham untuk menarik perhatian investor dengan memberikan sinyal bahwa perusahaan memiliki kondisi dan prospek yang bagus (Khomsiyah dan Sulistyo, 2001). Pemecahan saham digunakan emiten untuk menunjukkan kredibilitas sebagai perusahaan dengan kinerja keuangan yang bagus karena pemecahan saham memerlukan biaya sehingga perusahaan yang bagus saja yang mampu melakukannya. Sinyal pertama dan yang paling mudah ditangkap oleh investor adalah sinyal yang menggambarkan kondisi perusahaan itu baik atau tidak yaitu dari kinerja keuangannya.

Salah satu informasi akuntansi yang paling besar proporsinya adalah informasi mengenai laba tahunan (Beaver dalam 
Ewijaya dan Indriantoro, 1999). Dalam penelitian ini, kinerja keuangan yang mudah dan secara langsung dapat disinyalkan dari laporan keuangan yang dipublikasikan oleh perusahaan adalah laba bersih sesudah pajak (Earning After Tax), pertumbuhan laba bersih sesudah pajak dan laba per lembar saham (Earning Per Share). Investor akan dapat mudah menangkap sinyal tersebut dengan menilai perusahaan untung atau rugi, mencermati pertumbuhan laba yang diperoleh perusahaan, dan bagian laba per lembar saham. Semakin besar laba bersih sesudah pajak, pertumbuhan laba bersih sesudah pajak dan laba per lembar saham menunjukkan kinerja perusahaan dalam kondisi yang baik. Perusahaan berharap dengan mensinyalkan kondisi tersebut akan menarik investor berpartisipasi dalam perdagangan sahamnya.

Apabila peristiwa pengumuman pemecahan saham mempunyai kandungan informasi mengenai laba perusahaan di masa depan maka besarnya faktor pemecahan (split factor) seharusnya dapat dipakai sebagai sinyal bagi investor dalam mengambil keputusan investasi. Hal ini terutama berlaku bagi perusahaan yang melakukan pemecahan saham dengan split factor yang kecil, karena split factor yang kecil tentunya secara efektif tidak dapat menurunkan harga saham ke optimal trading range. Oleh karena itu signaling theory seharusnya menjadi latar belakang yang memotivasi perusahaan melakukan pemecahan saham. Split factor ini dapat dipakai sebagai sinyal karena mencerminkan informasi privat yang dimiliki pihak manajemen perusahaan dan belum diketahui oleh investor. Informasi tersebut terkait dengan peningkatan prospek dan kondisi perusahaan di masa depan, khususnya yang terkait dengan kinerja keuangan.

Beberapa penelitian yang terkait dengan ini di antaranya Brennan dan Copeland, Brennan dan Hughes (dalam Huang, Liano dan Pan, 2002) yang mengemukakan bahwa besaran split factor mensinyalkan informasi tertentu. Marwata (2001) membuktikan bahwa pemecahan saham membawa sinyal positif tentang kondisi perusahaan yang diperlihatkan dengan peningkatan laba dari tahun ketiga sampai tahun ke satu sebelum pemecahan saham. Pengujian Annafi' (2007) membuktikan bahwa ada perbedaan laba dan pertumbuhan laba antara perusahaan yang melakukan pemecahan saham dan tidak. Hasil ini kontradiktif dengan temuan Khomsiyah dan Sulistyo (2001) yang tidak menemukan faktor pertumbuhan laba sebagai variabel yang memengaruhi keputusan pemecahan saham.

Dengan melihat hasil penelitian terdahulu yang masih belum konsisten maka penelitian ini bertujuan untuk menguji apakah peristiwa pemecahan saham dapat dipakai oleh investor sebagai sinyal mengenai laba perusahaan bersangkutan di masa yang akan datang. Apabila peristiwa pemecahan saham merupakan sinyal yang tepat untuk laba maka terdapat pengaruh positif variabel split factor signal sebagai proksi informasi privat yang dimiliki perusahaan terhadap besaran laba perusahaan.

\section{METODE}

Populasi dalam penelitian ini adalah perusahaan yang melakukan pengumuman pemecahan di Bursa Efek Indonesia selama periode Januari 2002- Desember 2008. 
Teknik pengambilan sampel yang dipakai dalam penelitian ini adalah purposive sampling, yaitu teknik penentuan sampel dengan kriteria tertentu. Adapun kriteria yang digunakan adalah perusahaan yang melakukan pemecahan saham dengan jenis split up; perusahaan masih terdaftar di bursa selama satu tahun setelah peristiwa pemecahan saham; perusahaan yang memiliki Earning After Tax (EAT) dan Return on Equity (ROE) positif; dan perusahaan yang memiliki kelengkapan data yang diperlukan dalam penelitian. Sesuai dengan kriteria yang telah ditentukan maka diperoleh 55 pemecahan saham sebagai sampel.

Variabel terikat dalam penelitian ini adalah kinerja keuangan perusahaan. Penelitian ini menggunakan ukuran kinerja keuangan dengan tiga proksi yang berbeda yaitu:

1. Laba bersih sesudah pajak (Earning After Tax)

Earning adalah alat manajemen yang digunakan untuk mengukur besarnya bagian laba dan menilai pertumbuhan laba yang diperoleh perusahaan dan pemegang saham. Laba bersih yang dipakai dalam penelitian ini adalah laba bersih sesudah pajak yang tercantum dalam laporan keuangan akhir tahun.

2. Pertumbuhan laba bersih

Pertumbuhan laba bersih adalah selisih antara laba bersih sesudah pajak satu tahun sebelum pemecahan saham dengan laba bersih sesudah pajak pada tahun pemecahan saham.

3. Laba per lembar saham (Earning per Share)

Laba per lembar saham diperoleh dengan membagi laba bersih setelah pajak dengan jumlah lembar saham yang beredar. Data yang digunakan adalah data akhir tahun yang tercantum dalam laporan keuangan.

Variabel bebas dalam penelitian ini adalah split factor signal, yaitu informasi privat yang dimiliki oleh perusahaan pada saat melakukan pemecahan saham dan dipakai sebagai sinyal kondisi perusahaan di masa depan (Huang, Liano dan Pan, 2002). Perhitungan split factor signal mengacu pada pengujian McNichols dan Dravid (1990), Nayak dan Prabhala (2001) dan Huang, Liano dan Pan (2002) memakai persamaan regresi sebagai berikut:

SPR $=\beta_{0}+\beta_{1}$ PRICE $+\beta_{2} \mathrm{MV}+\beta_{3} \mathrm{RUNUP}+$ Split Signal

Keterangan:

SPR = Ukuran split ratio perusahaan yang melakukan pemecahan saham yang dihitung dari (jumlah lembar saham sesudah pemecahan-sebelum pemecahan)/ lembar saham sebelum pemecahan.

PRICE = Harga saham lima hari sebelum pemecahan saham

MV = Logaritma natural kapitalisasi pasar perusahaan

RUNUP = Rasio harga saham lima hari sebelum pemecahan saham dengan harga saham satu tahun sebelum pemecahan saham

Split Signal = Split factor signal (residual regresi)

Selain itu penelitian ini menggunakan satu variabel kontrol yaitu Return on Equity (ROE) dengan alasan berdasar penelitian terdahulu yaitu Freeman et al. (1982) dan Huang, Liano dan Pan (2002) ROE 
berpengaruh terhadap besaran laba perusahaan. ROE dihitung dengan membagi laba bersih sesudah pajak dengan nilai ekuitas saham biasa.

Teknik pengumpulan data yang digunakan dalam penelitian ini adalah teknik dokumentasi. Data sekunder yang digunakan dalam penelitian ini didapat dari Indonesian Capital Market Directory dan www.idx.co.id. Penelitian ini menggunakan teknik analisis data regresi linier berganda. Sebelum dilakukan pengujian hipotesis terlebih dahulu dilakukan uji prasyarat analisis data yang meliputi uji normalitas, multikolinearitas, heteroskedastisitas dan autokorelasi. Penelitian ini menggunakan tiga persamaan regresi yang masing-masing diuji secara terpisah yaitu:

EAT $=\beta_{0}+\beta_{1}$ Split Factor Signal $+\beta_{2} \mathrm{ROE}+\varepsilon$ $\Delta \mathrm{EAT}=\beta_{0}+\beta_{1}$ Split Factor Signal $+\beta_{2} \mathrm{ROE}+\varepsilon$ EPS $=\beta_{0}+\beta_{1}$ Split Factor Signal $+\beta_{2} \mathrm{ROE}+\varepsilon$ Keterangan:

$\begin{aligned} \text { EAT = } & \text { Laba bersih sesudah pajak } \\ \Delta \text { EAT = } & \text { Pertumbuhan laba bersih } \\ & \text { sesudah pajak } \\ \text { EPS = } & \text { Laba per lembar saham }\end{aligned}$

Split Factor Signal = Informasi privat dalam pemecahan saham

ROE = Return on Equity

$\varepsilon=$ error term

Hipotesis akan diterima apabila nilai signifikansi yang diharapkan lebih kecil dibandingkan alpha sebesar 5\% dengan arah yang sama. Dengan demikian hipotesis terbukti apabila masing-masing koefisien regresi $\beta_{1}$ di tiap-tiap persamaan bernilai positif dan signifikan artinya semakin besar kandungan informasi dalam pemecahan saham (split factor signal) maka semakin besar pula laba perusahaan. Selain itu juga akan dilihat besaran Adjusted $R^{2}$ untuk mengetahui kemampuan variabel dependen menjelaskan variabilitas variabel independen. Semakin tinggi nilai Adjusted $R^{2}$ berarti model penelitian ini semakin bagus karena semakin banyak variabilitas variabel dependen yang dapat diterangkan melalui variabel independen yang dipilih.

\section{HASIL DAN PEMBAHASAN}

Sebelum dilakukan pengujian hipotesis terlebih dahulu dilakukan uji prasyarat analisis berupa uji asumsi klasik sehingga regresi memenuhi kaidah BLUE (Best Linear Unbiased Estimator) (Hair et al., 1998). Pengujian normalitas dilakukan melalui One Sample Kolmogorov Smirnov. Hasilnya memperlihatkan bahwa residual ketiga persamaan regresi dalam penelitian ini memiliki signifikansi lebih besar dibandingkan alpha sebesar $5 \%$ sehingga disimpulkan regresi terdistribusi normal. Pengujian autokorelasi menggunakan uji Durbin Watson dan semua angka terletak di daerah bebas autokorelasi. Pendeteksian multikolinearitas menggunakan nilai Tolerance dan VIF. Hasilnya memperlihatkan bahwa ketiga persamaan regresi memiliki nilai Tolerance di atas 0,1 dan nilai VIF di bawah 10 sehingga regresi terbebas dari masalah multikolinearitas. Pengujian asumsi klasik selanjutnya adalah heteroskedastisitas yang dilakukan dengan metode Glejser yaitu meregresikan nilai absolut residual dengan variabel bebas. Hasil pengujian menyimpulkan bahwa tidak ada satu pun koefisien regresi yang memiliki signifikansi lebih kecil dari alpha sebesar 5\%. Dengan demikian maka regresi memenuhi asumsi homoskedastisitas. 
Tabel 1. Hasil Analisis Regresi Menggunakan Laba Bersih Sesudah Pajak sebagai Variabel Dependen

\begin{tabular}{lccc}
\hline Variabel & Koefisien Regresi & t-hitung & Signifikansi \\
\hline Konstanta & 2,592 & 7,436 & 0,000 \\
\hline Split Factor Signal & 0,044 & 2,362 & 0,022 \\
\hline ROE & 1,032 & 13,947 & 0,000 \\
\hline F hitung $=97,273$ & & & \\
\hline Signifikansi $=0,000$ & & & \\
\hline Adjusted $R^{2}=0,781$ & & \\
\hline
\end{tabular}

Berdasarkan hasil regresi di atas informasi privat yang terkandung dalam diperoleh koefisien regresi variabel split factor signal sebesar 0,044 dan signifikansi sebesar 0,022. Hasil ini menunjukkan bahwa split factor signal sebagai proksi informasi privat yang terkandung dalam peristiwa pemecahan saham berpengaruh positif terhadap kinerja keuangan yang diukur melalui laba bersih sesudah pajak pemecahan saham sebesar 1,250E7 dengan nilai signifikansi 0,827 . Temuan ini memperlihatkan bahwa split factor signal tidak berpengaruh terhadap kinerja keuangan yang diukur dengan pertumbuhan laba bersih sesudah pajak. Nilai F hitung untuk model kedua ini sebesar 7,226 dengan perusahaan. Nilai $F$ hitung sebesar 97,273 dengan nilai signifikansi 0,00 yang bermakna bahwa terdapat goodness of fit dari model regresi. Nilai Adjusted $R^{2}$ menunjukkan kemampuan model untuk menjelaskan variasi variabel dependen laba bersih sesudah pajak sebesar $78,10 \%$ dan sisanya sebesar 20,9\% dijelaskan oleh variabel lain di luar model regresi.

Berdasarkan Tabel 2 nilai koefisien variabel split factor signal yang merupakan nilai signifikansi 0,002 yang bermakna model dapat dipakai untuk prediksi karena terdapat goodness of fit. Kemampuan variabel independen untuk menjelaskan variasi pertumbuhan laba bersih sesudah pajak ditunjukkan melalui nilai Adjusted $R^{2}$ sebesar $18,70 \%$ sedangkan sisanya sebesar $81,30 \%$ dijelaskan oleh variabel lain di luar model.

Sesuai dengan Tabel 3 nilai koefisien regresi informasi privat dalam pemecahan saham yang diproksikan dengan split factor signal sebesar 3,603 dan nilai signifikansi

Tabel 2. Hasil Analisis Regresi Menggunakan Pertumbuhan Laba Bersih Sesudah Pajak sebagai Variabel Dependen

\begin{tabular}{lrrr}
\hline Variabel & Koefisien Regresi & t-hitung & Signifikansi \\
\hline Konstanta & $-5,891 \mathrm{E} 8$ & $-2,196$ & 0,033 \\
Split Factor Signal & $1,250 \mathrm{E} 7$ & 0,220 & 0,827 \\
ROE & $5,408 \mathrm{E} 7$ & 3,772 & 0,000 \\
\hline F hitung $=7,226$ & & & \\
\hline Signifikansi $=0,002$ & & & \\
\hline Adjusted $R^{2}=0,187$ & & \\
\hline
\end{tabular}


Tabel 3. Hasil Analisis Regresi Menggunakan Laba Per Lembar Saham sebagai Variabel Dependen

\begin{tabular}{lrrr}
\hline Variabel & Koefisien Regresi & t-hitung & Signifikansi \\
\hline Konstanta & $-69,382$ & $-0,780$ & 0,439 \\
\hline Split Factor Signal & 3,603 & 0,191 & 0,849 \\
\hline ROE & 12,550 & 2,640 & 0,011 \\
\hline F hitung $=3,528$ & & & \\
\hline Signifikansi $=0,037$ & & & \\
\hline Adjusted $R^{2}=0,086$ & & \\
\hline
\end{tabular}

0,849. Hal ini berarti bahwa split factor signal tidak berpengaruh terhadap kinerja keuangan perusahaan yang diproksikan dengan laba per lembar saham. Model ketiga ini memiliki nilai $F$ hitung 3,528 dengan signifikansi 0,037 sehingga disimpulkan terdapat goodness of fit model regresi. Nilai Adjusted $R^{2}$ model ketiga ini cukup kecil yaitu sebesar 0,086 yang bermakna bahwa variabel independen mampu menjelaskan variasi laba per lembar saham sebesar $8,6 \%$ dan sisanya sebesar $91,4 \%$ dijelaskan oleh variabel lain yang tidak digunakan dalam model.

Berdasarkan hasil uji hipótesis yang dilakukan terlihat bahwa peristiwa pemecahan saham tidak sepenuhnya dapat digunakan pasar sebagai sinyal atas kinerja keuangan perusahaan. Hal ini terbukti dari hasil penelitian yang menunjukkan bahwa split factor signal sebagai proksi informasi privat yang dimiliki perusahaan hanya berpengaruh terhadap kinerja keuangan yang berupa laba bersih sesudah pajak. Sedangkan kinerja keuangan yang lainnya yaitu pertumbuhan laba bersih sesudah pajak dan laba per lembar saham tidak dipengaruhi oleh informasi privat yang terkandung dalam peristiwa pemecahan saham. Hasil yang memperlihatkan pengaruh positif split factor signal terhadap laba bersih ini mendukung keberadaan signalling theory sebagai teori yang mendasari alasan perusahaan melakukan pemecahan saham. Melalui peristiwa pemecahan saham perusahaan ingin memberikan sinyal positif kepada publik mengenai kondisi keuangan yang tercermin dari laba bersih. Dengan demikian maka peristiwa pemecahan saham dapat dimanfaatkan investor untuk membantu pengambilan keputusan investasi di mana perusahaan yang melakukan pemecahan saham dianggap memiliki prospek yang cerah di masa depan. Hasil penelitian ini konsisten dengan penelitian sebelumnya yang dilakukan oleh Marwata (2001) yang mengindikasikan bahwa pemecahan saham membawa sinyal positif tentang kondisi perusahaan.

\section{SIMPULAN}

Hasil penelitian menunjukkan bahwa split factor signal sebagai proksi informasi privat berpengaruh terhadap kinerja keuangan yang diukur dengan laba bersih sesudah pajak perusahaan. Ini bermakna bahwa peristiwa pemecahan saham memberikan sinyal yang positif seperti yang dihipotesiskan dalam signalling theory. Perusahaan melakukan pemecahan saham untuk menginformasikan kepada pasar bahwa 
mereka memiliki prospek yang baik di masa yang akan datang. Selain itu hasil penelitian juga menunjukkan bahwa split factor signal tidak berpengaruh terhadap kinerja keuangan yang diukur menggunakan pertumbuhan laba bersih sesudah pajak dan laba per lembar saham. Hal ini mengindikasikan bahwa informasi privat yang terkandung dalam pemecahan saham tidak dapat digunakan untuk memprediksi dua ukuran kinerja keuangan tersebut.

Temuan ini mengimplikasikan bahwa pemecahan saham dapat digunakan sebagai salah satu alat bagi perusahaan untuk memberikan sinyal positif kepada pasar mengenai kondisinya di masa yang akan datang. Meskipun pemecahan saham secara ekonomis tidak menambah kekayaan investor tetapi investor dapat memanfaatkan informasi privat yang terkandung dalam peristiwa ini sebagai indikator bahwa laba bersih perusahaan akan meningkat dan mengambil keputusan investasi yang tepat.

\section{DAFTAR PUSTAKA}

Annafi', D. H. (2007) Perbedaan Kinerja Keuangan dan Kemahalan Harga Saham Perusahaan yang Melakukan Pemecahan Saham dan Tidak Melakukan Pemecahan Saham (Studi Empiris pada Perusahaan yang Terdaftar di Bursa Efek Jakarta 20032006). Skripsi Tidak Dipublikasikan. Universitas Negeri Yogyakarta.

Cahyaning. (2005) Dampak Stock Split terhadap Return Saham (Perusahaan yang Melakukan Stock Split Periode 19992002). Skripsi Tidak Dipublikasikan. Universitas Muhammadiyah Yogyakarta.

Ewijaya dan Indriantoro, N. (1999) Analisis Pengaruh Pemecahan Saham Terhadap
Perubahan Harga Saham. Jurnal Riset Akuntansi Indonesia, 2(1), 53-65.

Fatmawati, S., dan Asri, M. (1998) Pengaruh Stock Split Terhadap Likuiditas Saham Yang Diukur Dengan Besarnya Bid-Ask Spread di Bursa Efek Jakarta. Jurnal Ekonomi dan Bisnis Indonesia, 14(4), 93110.

Freeman, R. N., Ohlson J.A., dan Penman, S. H.. (1982). Book Rate of Return and Prediction of Earnings Changes: An Empirical Investigation. Journal of Accounting Research, 20, 639- 653.

Hair et al. (1998) Multivariate Analysis. 5th Edition. Singapore: Prentice Hall International.

Hartono, J. (2003) Teori Portofolio dan Analisis Investasi. Edisi Ketiga, Yogyakarta: BPFE.

Haryanto, \& Hermawan, W.D. (2005) Pengaruh Pemecahan Saham Terhadap Likuiditas dan Abnormal Return Saham Perusahaan di Bursa Efek Jakarta. Jurnal Buletin Ekonomi, 3(3), 209-228.

Huang, G.C, Liano, K., Pan, M.S. (2002) Do Stock Split Signal Future Profitability? Working Paper. Alabama State University. www.ssrn.com

Khomsiyah \& Sulistyo. (2001) Faktor Tingkat Kemahalan Harga Saham, Kinerja Keuangan Perusahaan dan Keputusan Pemecahan Saham (Stock split): Aplikasi Analisis Diskriminan. Jurnal Ekonomi dan Bisnis Indonesia, 16(4), 388-400.

Kurniawati, I. (2003) Analisis Kandungan Informasi Stock split dan Likuiditas: Studi Empiris pada Non-Synchronous Trading. Jurnal Riset Akuntansi, 6(3), 264-275.

Margaretha, F. (2003) Tinjauan Persepsi Manajemen Terhadap Struktur Modal Perusahaan Go Public. Media Riset Bisnis dan Manajemen, 3, 98-115. 
Jurnal Economia, Volume 11, Nomor 2, Oktober 2015

Marwata. (2001) Kinerja Keuangan, Harga Saham, dan Pemecahan Saham. Jurnal Riset Akuntansi Indonesia, 4(2), 151-164.

McNichols, M., \& Dravid, A. (1990) Stock Dividends, Stock Splits, and Signaling. Journal of Finance 45, 857-879.

Miliasih, R. (2000) Analisis Pengaruh Stock Split terhadap Earning. Jurnal Bisnis dan Akuntansi, 2(2), 131-144.
Nayak, S. dan Prabhala, N. R. (2001) Disentangling the Dividend Information in Splits: A Decomposition Using Conditional Event-Study Methods. Review of Financial Studies 14, 10831116.

Sukardi. (2000) Reaksi Pasar Terhadap Stock Split. Aplikasi Bisnis, 1(1), 24-29. 